\title{
Yield of the Okra Submitted to Nitrogen Rates and Wastewater in Northeast Brazilian Semiarid Region
}

\author{
Aldair de Souza Medeiros ${ }^{1}$, Manoel Moisés Ferreira de Queiroz ${ }^{2}$, Renato A. de Araújo Neto ${ }^{1}$, \\ Patrícia da Silva Costa ${ }^{3}$, Amanda Costa Campos ${ }^{3}$, Rener Luciano de Souza Feraz ${ }^{4}$, Ivomberg Dourado Magalhães ${ }^{1}$, \\ Sebastião de Oliveira Maia Júnior ${ }^{1}$, Luan Danilo Ferreira de Andrade Melo ${ }^{1}$ \\ \& Giordano Bruno Medeiros Gonzaga ${ }^{1}$ \\ ${ }^{1}$ Department of Plant Production, Federal University of Alagoas, Maceió, Brazil \\ ${ }^{2}$ Academic Unit of Agricultural Science, Federal University of Campina Grande, Pombal, Brazil \\ ${ }^{3}$ Department of Animal Science, Federal University of Campina Grande, Patos, Brazil \\ ${ }^{4}$ Academic Unit of Agricultural Engineering, Federal University of Campina Grande, Campina Grande, Brazil \\ Correspondence: Rener Luciano de Souza Ferraz, Academic Unit of Agricultural Engineering, Federal \\ University of Campina Grande, Campina Grande, Paraíba, Brazil. Tel: 55-083-99619-3860. E-mail: \\ ferragroestat@gmail.com
}

Received: January 8, 2018

Accepted: February 23, $2018 \quad$ Online Published: March 15, 2018

doi:10.5539/jas.v10n4p409

URL: https://doi.org/10.5539/jas.v10n4p409

\begin{abstract}
Water is an indispensable resource for the maintenance of life; however, the available volume for consumption has decreased over a period of life, as a result of which, the availability of water that is inferior in quality has increased. In this context, we aimed to evaluate the growth and yield of okra (Santa Cruz cultivar) under different nitrogen rates and irrigation facilities using post-treated domestic wastewater through sand filter with intermittent flow in a Brazilian semiarid region. The experiment was performed in the Pombal region of the Paraíba state, Brazil using a randomized block design with six nitrogen Rates $\left(\mathrm{N}_{1}=0, \mathrm{~N}_{2}=40, \mathrm{~N}_{3}=80, \mathrm{~N}_{4}=\right.$ $120, \mathrm{~N}_{5}=160$, and $\mathrm{N}_{6}=200 \mathrm{~kg} \mathrm{ha}^{-1}$ ) and irrigation by using wastewater. The water was added to the treatment with $100 \%\left(160 \mathrm{~kg} \mathrm{ha}^{-1}\right)$ using nitrogen fertilization recommendation and irrigation water supply. The effects of treatments on the growth and production variables of okra plants were evaluated.
\end{abstract}

Keywords: Abelmoschus esculentus L., nitrogen fertilization, semiarid region, water reuse

\section{Introduction}

Okra (Abelmoschus esculentus L.) is a plant of the Malvaceae family, which originated in Africa and is rich in carbohydrates, proteins, vitamins, minerals, and unsaturated fats (Omotoso \& Shittu, 2007; Zubairu et al., 2017). Due to the plants rusticity characteristics, mainly the tolerance to high temperatures during cultivation (Oliveira et al., 2014), the Brazilian Northeast semiarid regions offer excellent climatic conditions for the cultivation of this vegetable.

However, the semiarid regions are characterized by irregular rainfall in spatial and temporal distribution (Akande et al., 2010). Therefore, the irrigation is a fundamental technology to ensure agricultural production in these regions (Anjos et al., 2017). In order to mitigate the water-scarcity problem, some researchers evaluated the viable alternatives such as the use of "inferior quality" water in agriculture, especially the use of saline and wastewater (Medeiros et al., 2015; Souza et al., 2016).

According to Kummer et al. (2017), and Medeiros et al. (2017), the adequately treated and managed wastewater (WW) becomes a water source alternative, allowing agricultural production and surface water economy in some regions that water deficit. In addition to being a water source, WW provides macro and micronutrients to plants, mainly nitrogen (N) (Medeiros et al., 2015). In this way, the reutilization of nutrients is promoted by the agricultural crops and the application of synthetic fertilizers is reduced.

Nitrogen is the second-most absorbed nutrient by vegetables, which plays a fundamental role in their yield (Souza et al., 2017), which is an essential macronutrient during the growth and development of a plant. The proper management of this nutrient contributes to the vegetative growth and increase in the productivity of the 
cultures; therefore, it performs important structural function and is a part of several organic compounds that are essential for the plants, such as amino acids, proteins, and proline (Olaniyi et al., 2010; Ferraz et al., 2017; Medeiros et al., 2017).

In the okra culture, $\mathrm{N}$ provides greater response in the fruit production (Zubairu et al., 2017) as well as to obtain satisfactory yields. There are several recommendations of this nutrient, varying from 60 to $180 \mathrm{~kg} \mathrm{ha}^{-1}$, depending on the soil fertility of the growing region (Oliveira et al., 2014). However, there is little knowledge regarding the ideal amounts to be supplied when using wastewater for irrigation of plants in a semiarid region. In this context, the aim of this study was to evaluate the effect of different nitrogen rates associated with post-treated domestic wastewater irrigation in a sand filter intermittent flow on the growth and yield of okra in a Brazilian semi-arid region of Pombal in Paraiba.

\section{Material and Methods}

\subsection{Localization, Experimental Procedure, Treatments and Plant Material}

The experiment was conducted from July to October 2014 at the Agrifood Technology Science Center (CCTA) in the Federal University of Campina Grande (UFCG), Pombal city, Paraíba state, northeast of Brazil. The Pombal's climate classification (according to Köppen) is a BSh-type, representing hot and dry semiarid climate, with an average precipitation of $750 \mathrm{~mm}_{\text {year }}{ }^{-1}$ and an average annual evaporation of $2000 \mathrm{~mm}$.

The treatments resulted in six nitrogen Rates $\left(\mathrm{N}_{1}=0, \mathrm{~N}_{2}=40, \mathrm{~N}_{3}=80, \mathrm{~N}_{4}=120, \mathrm{~N}_{5}=160\right.$, and $\mathrm{N}_{6}=200 \mathrm{~kg}$ $\mathrm{ha}^{-1}$ ), corresponding respectively to $0,25,50,75,100$, and $125 \%$ of the fertilization recommendation for the okra crop, as suggested by Oliveira et al. (2003), with the addition of WW in the irrigation. In addition to these treatments, a control was added, whose plants received $100 \%$ of the recommended Rate of $\mathrm{N}$ and were irrigated with a water supply (IW), wherein, this treatment was compared with the treatments that received a minimum $(0 \%)$ of the recommended $(100 \%)$ Rates of $\mathrm{N}$ fertilization and were irrigated with WW. The experimental design was randomized blocks, with 6 treatments $(+1)$ and four replications, totaling 28 experimental units.

The Santa Cruz okra cultivar was used, because it was extremely productive and most planted in the region, and plastic lysimeters for the conduction of the plants with 500-L capacity, filled with a layer of $15-\mathrm{cm}$ of gravel $\left(\mathrm{n}^{\circ}\right.$ 0 ) covering the base of the lysimeter to facilitate the drainage of water. Then, it was completely filled with soil material, classified as Fluvent, sandy-loam, non-saline, and non-sodic, with the material coming from the municipality of Pombal, Paraíba. The chemical and physical soil characteristics used in the experiment (Table 1) were determined according to the methodologies recommended by Embrapa (1997).

Table 1. Chemical and physical attributes of the soil used during the experiment



After conditioning in the lysimeters, the soil was placed in the field capacity (CC) through the capillary saturation method, followed by free drainage using water supply. The crop planting was performed by means of no-till, with five seeds per plot (lysimeter), and at 20 days after emergence (DAE), thinning was performed, leaving two plants with greater vigor.

The source of $\mathrm{N}$ was urea $(45 \% \mathrm{~N})$, and losses by volatilization and/or leaching were reduced by nitrogen fertilization plotted in three coverage applications for every 10 DAE. The cultural treatments carried out during the crop cycle were phytosanitary control, mainly of aphids (Aphis gossypii) and scale insects (Dactylopiuscoccus), with the applications of $100 \mathrm{~mL}$ of systemic insecticide Evidence ${ }^{\circledR} 700 \mathrm{WG}$ (concentration 
$\left.1 \mathrm{~g} \mathrm{~L}^{-1}\right)$ in the soil via irrigation. The control of spontaneous plants from manual weeds within the lysimeters was performed at weekly intervals.

The WW used in the experiment came from showers, sinks, and urinals of the bathrooms located at the UFCG, Campus ofPombal. The collection was performed through pipes and the samples were deposited in a septic tank, which was connected by means of a tube inserted at the lower end to a container plastic with $500 \mathrm{~L}$ of capacity, functioning as an effluent distribution reservoir. This distribution occurred by piping up to three different intermittent aerobic filters (each filter receiving $50 \mathrm{~L}$ of WW every 6,8 , and $12 \mathrm{~h}$ ). The effluent produced was stored in a $500-\mathrm{L}$ plastic container. The filters were constructed by adapting $250-\mathrm{L}$ plastic containers; the lower part of the containers contained a 10-cm layer of gravel $\left(\mathrm{n}^{\circ} .1\right)$, followed by a layer of $50 \mathrm{~cm}$ of sand. The upper part contained another layer of $5 \mathrm{~cm}$ of gravel to standardize the flow.

Table 2 shows the mean values of physical-chemical parameters of WW before and after treatment with sand filter, according to the method described by Sousa (2015). The results of the quality analysis of WW after the use of sand filter is within the standards recommended by CONAMA (2005).

Table 2. Physical-chemical characteristics of septic tank wastewater and after the sand filters

\begin{tabular}{|c|c|c|c|c|c|c|c|c|c|c|c|c|}
\hline \multicolumn{13}{|c|}{ WW septic tank } \\
\hline $\mathrm{pH}$ & $\mathrm{EC}$ & $\mathrm{DO}$ & $\mathrm{Ca}$ & $\mathrm{Mg}$ & $\mathrm{Cl}^{-}$ & $\mathrm{P}$ & $\mathrm{N}$ & $\mathrm{Na}$ & $\mathrm{K}$ & COD & BOD & RAS \\
\hline & $\mathrm{dS} \mathrm{m}^{-1}$ & $\begin{array}{cc}----1 \\
\end{array}$ & $-\cdots$ & 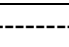 & 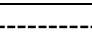 & - & $\operatorname{lg~L}^{-1}$ & - & 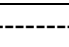 & ------- & ------ & $\mathrm{mmol} \mathrm{L}^{-1}$ \\
\hline 8.3 & 0.82 & 0.4 & 34.4 & 25.4 & 102.5 & 0.8 & 0.01 & 0.02 & 0.09 & 89.8 & 15.6 & 3.6 \\
\hline \multicolumn{13}{|c|}{$W W$ after the sand filters } \\
\hline $\mathrm{pH}$ & $\mathrm{EC}$ & OD & $\mathrm{Ca}$ & $\mathrm{Mg}$ & $\mathrm{Cl}^{-}$ & $\mathrm{P}$ & $\mathrm{N}$ & $\mathrm{Na}$ & $\mathrm{K}$ & COD & BOD & RAS \\
\hline & $\mathrm{dS} \mathrm{m}^{-1}$ & --- & ----- & - & - & ----- & $\operatorname{lg~L}^{-1}$ & ---- & --- & ------- & ------- & $\mathrm{mmol} \mathrm{L}^{-1}$ \\
\hline 6.2 & 0.56 & 6.4 & 58.4 & 44.0 & 86.2 & 0.7 & 0.01 & 0.01 & 0.0 & 127.3 & 25.4 & 1.3 \\
\hline
\end{tabular}

Note. ${ }^{*} \mathrm{pH}$ : hydrogenionic potential; EC: electrical conductivity; DO: dissolved oxygen; Ca: calcium; Mg: magnesium, $\mathrm{Cl}$ : chlorides; P: phosphorus; $\mathrm{N}$ : nitrogen; Na: sodium; K: potassium; COD: chemical oxygen demand; BOD: biochemical oxygen demand; RAS: sodium adsorption.

\subsection{Data Measurement}

At $78 \mathrm{DAE}$, the effects of treatments on plant height $(\mathrm{PH}$, in $\mathrm{cm})$ were evaluated by measuring the distance between the plant's neck at the base of the youngest leaf using a measuring tape; the number of leaves (LN), considering only the leaves with complete development; the diameter of the stem (SD, in $\mathrm{mm}$ ) was determined at 3 $\mathrm{cm}$ from the lap of the plants using a digital caliper; and leaf area $\left(\mathrm{LA}, \mathrm{in} \mathrm{cm}^{2}\right)$, as per the methodology of Severino et al. (2005), as follows:

$$
\mathrm{LA}=0.84 \times(\mathrm{P}+\mathrm{L}) 0.99
$$

Where, A: leaf area, in $\mathrm{cm}^{2}$; $\mathrm{P}$ : main rib length, in $\mathrm{cm}$; L: sheet width, in $\mathrm{cm}$.

The okra production was evaluated at 90 DAE, by determining the number of fruits per plot (NFP); diameter of the fruit (DF, in $\mathrm{mm}$ ); fruit length (CF, in $\mathrm{cm})$; unit weight of a fruit (PUF, in $\mathrm{g})$; and production per plot (PROD, in $\mathrm{g}$ ).

\subsection{Statistical Analysis}

The data were submitted to analysis of variance by F-test $(p<0.05)$. In case of detection of significance, polynomial regression analysis was performed for the Rate unfolding of N. Tukey's test was performed to compare the means of the treatment irrigated with water supply and receiving $100 \%$ Rate $\left(160 \mathrm{~kg} \mathrm{ha}^{-1}\right)$ of N, according to the recommendation (Witness), with those that were irrigated with wastewater and received $0 \%$ ( 0 $\left.\mathrm{kg} \mathrm{ha}^{-1}\right)$ and $100 \%\left(160 \mathrm{~kg} \mathrm{ha}^{-1}\right)$ of the $\mathrm{N}$ recommendation. These analyses were performed using the statistical software SISVAR (Ferreira, 2014).

\section{Results and Discussion}

As seen in Table 3, the increment in the N Rates significantly influenced $(p<0.01)$ only the leaf area (LA) of the okra plants. As for the comparison test between the means, it was observed that different types of water used in the irrigation of the plants (WW and IW) had a significant influence on all studied variables. However, differing results were reported by Firoz (2009), and Zubairu et al. (2017), who evaluated the effect of nitrogen fertilization on okra cultivation and found a linear increase in $\mathrm{PH}$ up to the maximum limit of $120 \mathrm{~kg} \mathrm{ha}^{-1}$ of $\mathrm{N}$. This 
divergence may be attributed to the lower quantity of $\mathrm{N}$ in the soils of the study region as well as the lack of the use of WW in the irrigation of the plants.

The absence of significant effects on the other evaluated parameters revealed that the adequate supply of $\mathrm{N}$, that is, only the nutrients present in the soil together with those of the WW were sufficient to guarantee the growth of the plants, the development of the stem, and that of the leaves of the okra. The results obtained in this study confirmed the information provided by the other authors, Medeiros et al. (2015), Sousa (2015), Kummer et al. (2017), and Medeiros et al. (2017) when they reported that WW is a nutritional source for plants, especially macronutrients, which promotes the reuse of nutrients by crops.

Table 3. Summary of analysis of variance for the variables' plant height (PH), stem diameter (SD), leaf number (LN), and leaf area (LA) of okra cv. Santa Cruz under nitrogen fertilization and irrigation with wastewater

\begin{tabular}{|c|c|c|c|c|c|}
\hline \multirow{2}{*}{ Source of Variation } & \multirow{2}{*}{ GL } & \multicolumn{4}{|c|}{ Medium Squares } \\
\hline & & $\mathrm{PH}$ & SD & $\mathrm{LN}$ & LA \\
\hline Nitrogen $(\mathrm{N})$ & 5 & $415.537^{\mathrm{ns}}$ & $0.349^{\mathrm{ns}}$ & $31.718^{\mathrm{ns}}$ & $76909.839^{* *}$ \\
\hline Linear Regression & 1 & $1490.414^{\mathrm{ns}}$ & $1.358^{\mathrm{ns}}$ & $118.950^{\mathrm{ns}}$ & $374861.622^{* *}$ \\
\hline Quadratic Regression & 1 & $0.697^{\mathrm{ns}}$ & $0.005^{\mathrm{ns}}$ & $6.857^{\mathrm{ns}}$ & $5390.649^{\mathrm{ns}}$ \\
\hline Block & 3 & 77.849 & 0.130 & 2.204 & 300.038 \\
\hline Residue & 15 & 204.205 & 0.134 & 12.313 & 2037.212 \\
\hline $\mathrm{CV}(\%)$ & & 22.30 & 18.77 & 21.51 & 9.41 \\
\hline Treatments & & \multicolumn{4}{|c|}{ Averages } \\
\hline $\mathrm{N}_{1}\left(0 \mathrm{~kg} \mathrm{ha}^{-1}\right.$ de $\left.\mathrm{N}+\mathrm{WW}\right)$ & & $53.48 \mathrm{c}$ & $1.60 \mathrm{c}$ & $12.63 \mathrm{c}$ & $313.95 \mathrm{c}$ \\
\hline $\mathrm{N}_{4}\left(160 \mathrm{~kg} \mathrm{ha}^{-1}\right.$ de $\left.\mathrm{N}+\mathrm{WW}\right)$ & & $75.20 \mathrm{a}$ & $2.11 \mathrm{a}$ & $20.63 a$ & $589.09 \mathrm{a}$ \\
\hline Witness $\left(160 \mathrm{~kg} \mathrm{ha}^{-1} \mathrm{de} N+\mathrm{IW}\right)$ & & $65.75 b$ & $1.73 b$ & $15.75 b$ & $487.71 b$ \\
\hline
\end{tabular}

Note. ${ }^{*}$ ns: not significant, ${ }^{* *}$ : significant at $1 \%$ probability $(\mathrm{p}<0.01)$ by F-test; GL: number of degrees of freedom; CV: coefficient of variation. Means followed by the same letter in the column do not differ by Tukey's test at $5 \%$ probability level $(\mathrm{p}<0.05) . \mathrm{N}_{1}:\left(0 \mathrm{~kg} \mathrm{ha}^{-1}\right.$ of $\left.\mathrm{N}+\mathrm{WW}\right)$ : plants that received irrigation with wastewater and $0 \%$ of $\mathrm{N}$ recommendation; $\mathrm{N}_{4}:\left(160 \mathrm{~kg} \mathrm{ha}^{-1}\right.$ of $\left.\mathrm{N}+\mathrm{WW}\right)$ : plants that received irrigation with wastewater and $100 \%$ of $\mathrm{N}$ recommendation; witness $\left(160 \mathrm{~kg} \mathrm{ha}^{-1}\right.$ of $\left.\mathrm{N}+\mathrm{IW}\right)$ : plants that received irrigation with water and $100 \%$ of the N Rate recommended.

LA was linearly adjusted as a function of the $\mathrm{N}$ rate, with a steeper increase from the estimated Rate of $162.22 \mathrm{~kg}$ $\mathrm{ha}^{-1}$, with values varying from 313 to $679 \mathrm{~cm}^{2}$ (Figure 1). There were increases in the order of $0.62 \%$ per unit increase of the N Rate, that is, the LA of the okra plants increased to $365.32 \mathrm{~cm}^{2}(123.29 \%)$ at the maximum Rate of $\mathrm{N}\left(200 \mathrm{~kg} \mathrm{ha}^{-1}\right)$ in plants that did not receive nitrogen fertilization. The minimum LA observed in the absence of $\mathrm{N}$ may be attributed to the poor nutritional status of the plants subjected to this treatment, which has resulted in delayed leaf expansion (Olaniyi et al., 2010; Souza et al., 2016; Zubairu et al., 2017).

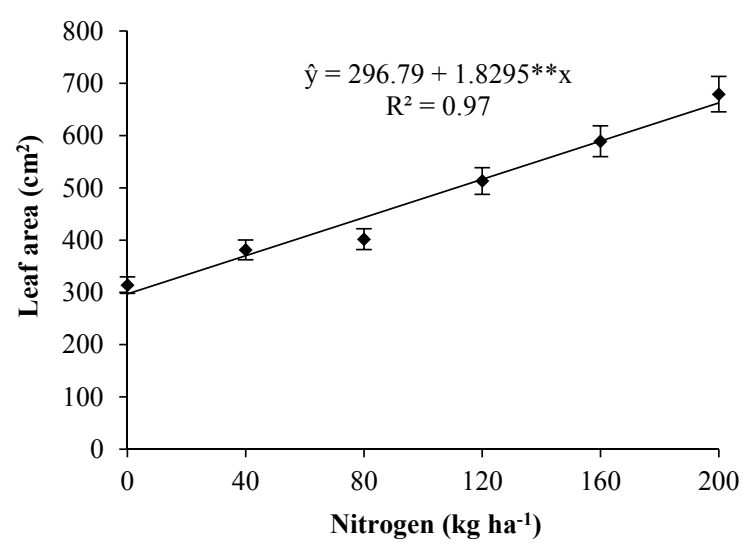

Figure 1. The leaf area of okra plants cultivated in Santa Cruz as a function of nitrogen Rates and irrigation with wastewater 
The positive effect of $\mathrm{N}$ on LA is related to the functions performed by this nutrient on the development of cultures, since this element helps in cell division and stretching; it plays an important role in chlorophyll, protein, nucleic acid, hormones, and synthesis of vitamins (Omotoso \& Shittu, 2007; Akande et al., 2010; Souza et al., 2017). In addition, it was found that LA responds positively to this element when supplied in adequate quantity (Akanbi et al., 2010). Since N deficiency results in delayed plant growth, thin stems, and less leaf expansion (Zubairu et al., 2017), excess deficiency caused restrictions as it promotes the saline effect in the soil, resulting in nutritional imbalance (Medeiros et al., 2015). In addition, it can prolong the vegetative cycle of the plant and delay flowering, which may cause oxidative damages that compromise important cellular components such as lipids, proteins, DNA, RNA and reducing plant growth, and yield (Akande et al., 2010; Medeiros et al., 2015; Medeiros et al., 2017; Souza et al., 2017; Zubairu et al., 2017).

These results reinforce the importance of $\mathrm{N}$ for plant growth and development, as this nutrient is required for the synthesis of several cellular components, especially for chlorophyll molecule and ribulose-1,5-biphosphate carboxylase oxygenase (Rubisco), which are responsible for $\mathrm{CO}_{2}$ assimilation during the photochemical and biochemical phases of photosynthesis (Medeiros et al., 2015; Souza et al., 2016; Medeiros et al., 2017). Akintomide and Osundare (2015) also reported a significant response of okra LA with N fertilization. Other authors like, Souza et al. (2016), and Souza et al. (2017) observed positive responses of N fertilization on the LA of several agricultural crops.

On the other hand, a distinct behavior was observed in the okra (Akanbi et al., 2010), wherein decreases in LA was noted with the application of Rates $>50 \mathrm{~kg} \mathrm{ha}^{-1}$ of N, which is a lower than usual Rate in this study. Medeiros et al. (2015) observed a linear decrease in the LA of eggplant with increasing Rates of $\mathrm{N}$ and irrigation with domestic WW under edaphoclimatic conditions in the semi-arid region of Paraíba.

The variables of production of the "Santa Cruz" okra cultivated under lysimeter conditions: the number of fruits per plot (NFP) and the yield per plot were significantly influenced by the Rates of $\mathrm{N}$ at $1 \%$ probability. In relation to the test of comparison between means, it was verified that the different types of water used in the irrigation of the plants (WW and IW) provided significant effects on all variables of okra production (Table 4). These results confirmed the reports of Kummer et al. (2017) and Medeiros et al. (2015, 2017), where they stated that part of the nutritional requirements of crops can be supplied by nutrients present in the wastewater itself.

Table 4. Summary of variance analyses for the number of fruits per plot (NFP), fruit diameter (FD), fruit length (FL), fruit unit weight (FUW), and okra production (PROD) under nitrogen fertilization and wastewater irrigation

\begin{tabular}{|c|c|c|c|c|c|c|}
\hline \multirow{2}{*}{ Source of Variation } & \multirow{2}{*}{ GL } & \multicolumn{5}{|c|}{ Medium Squares } \\
\hline & & NFP & FD & $\mathrm{FL}$ & FUW & PROD \\
\hline Nitrogen $(\mathrm{N})$ & 5 & $374.766^{* *}$ & $0.012^{\mathrm{ns}}$ & $4.224^{\mathrm{ns}}$ & $2.534^{\mathrm{ns}}$ & $497280.032^{* *}$ \\
\hline Linear Regression & 1 & $1770.057^{* *}$ & $0.039^{\mathrm{ns}}$ & $5.742^{\mathrm{ns}}$ & $11.583^{\mathrm{ns}}$ & $2445715.486^{* *}$ \\
\hline Quadratic Regression & 1 & $7.440^{\mathrm{ns}}$ & $0.016^{\mathrm{ns}}$ & $8.109^{\text {ns }}$ & $0.317^{\mathrm{ns}}$ & $7.248^{\mathrm{ns}}$ \\
\hline Block & 3 & $1.666^{\mathrm{ns}}$ & $0.001^{\mathrm{ns}}$ & $2.312^{\mathrm{ns}}$ & $1.888^{\mathrm{ns}}$ & $2250.848^{\mathrm{ns}}$ \\
\hline Residue & 15 & 2.833 & 0.007 & 1.683 & 6.296 & 3503.962 \\
\hline C.V. $(\%)$ & & 6.56 & 4.42 & 7.94 & 9.73 & 7.46 \\
\hline Treatments & & \multicolumn{5}{|c|}{ Averages } \\
\hline $\mathrm{N}_{1}\left(0 \mathrm{Kg} \mathrm{ha}^{-1} \mathrm{de} \mathrm{N}+\mathrm{WW}\right)$ & & $13 \mathrm{c}$ & $1.89 \mathrm{c}$ & $16.65 \mathrm{c}$ & $24.69 \mathrm{c}$ & $343.88 \mathrm{c}$ \\
\hline $\mathrm{N}_{4}\left(160 \mathrm{~kg} \mathrm{ha}^{-1}\right.$ de $\left.\mathrm{N}+\mathrm{WW}\right)$ & & $37 \mathrm{a}$ & $1.95 \mathrm{a}$ & $17.43 \mathrm{a}$ & $28.58 \mathrm{a}$ & $1043.63 \mathrm{a}$ \\
\hline Witness $\left(160 \mathrm{~kg} \mathrm{ha}^{-1}\right.$ de $\left.\mathrm{N}+\mathrm{IW}\right)$ & & $30 b$ & $1.91 \mathrm{~b}$ & $16.76 \mathrm{~b}$ & $26.25 b$ & $904.84 b$ \\
\hline
\end{tabular}

Note. ${ }^{*}$ ns: not significant, $* *$ : significant at $1 \%$ probability $(\mathrm{p}<0.01)$ by F-test; GL: number of degrees of freedom; CV: coefficient of variation. Means followed by the same letter in the column do not differ by Tukey's test at $5 \%$ probability level $(\mathrm{p}<0.05) . \mathrm{N}_{1}:\left(0 \mathrm{~kg} \mathrm{ha}^{-1}\right.$ of $\left.\mathrm{N}+\mathrm{WW}\right)$ : plants that received irrigation with wastewater and $0 \%$ of $\mathrm{N}$ recommendation; $\mathrm{N}_{4}:\left(160 \mathrm{~kg} \mathrm{ha}^{-1}\right.$ of $\left.\mathrm{N}+\mathrm{WW}\right)$ : plants that received irrigation with wastewater and $100 \%$ of $\mathrm{N}$ recommendation; witness $\left(160 \mathrm{~kg} \mathrm{ha}^{-1}\right.$ of $\left.\mathrm{N}+\mathrm{IW}\right)$ : plants that received irrigation with water and $100 \%$ of the N Rate recommended.

Figures $2 \mathrm{~A}$ and $2 \mathrm{~B}$ show the trends $(\mathrm{p}<0.01)$ of NFP and PROD as a function of N Rates $\left(\mathrm{kg} \mathrm{ha}^{-1}\right)$, and reveal that increases in $\mathrm{N}$ Rates result in substantial gains in these variables. The response of the use of $\mathrm{N}$ on the NFP and PROD was of a linear nature, showing that the maximum values of these parameters were respectively 38 
and $1,273.53 \mathrm{~g}$, with the maximum $\mathrm{N}$ Rate of $200 \mathrm{~kg} \mathrm{ha}^{-1}$. There was a mean increase in NFP and PROD in the order of $18 \%$ and $22 \%$, respectively, due to an increase in the $\mathrm{N}$ Rate, providing respective gains of $63 \%$ and $73 \%$ in the NFP and PROD, respectively, as obtained with the Rate of $200 \mathrm{~kg} \mathrm{ha}^{-1}$ of N in relation to the absence of nitrogen fertilizer. The maximum Rate of $\mathrm{N}$ promoted greater cell division and the formation of more tissues, which resulted in greater leaf expansion, increase in the root system, and the relationship between the leaf area and photosynthesis, which consequently influence fruit production (Omotoso \& Shittu, 2007; Zubairu et al., 2017).

A

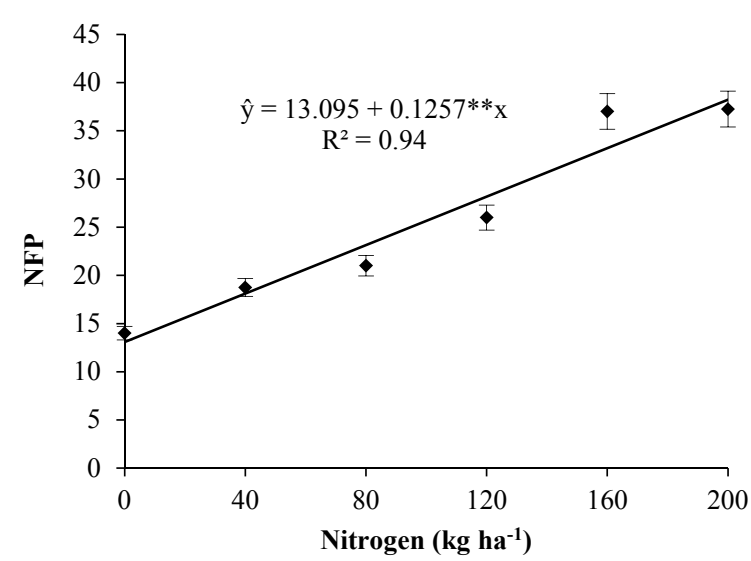

B

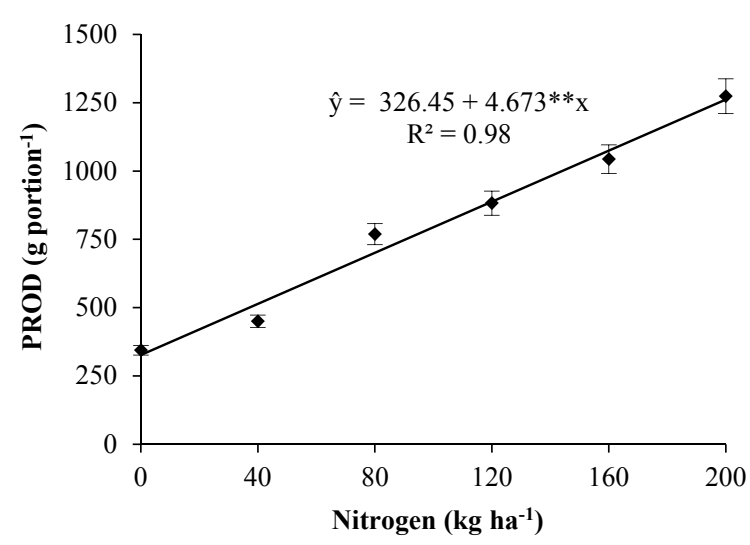

Figure 2. Number of fruits per plot (A) and yield per plot (B) of the Santa Cruz okra cultivar as a function of nitrogen Rates and irrigation with wastewater

These results showed that, although it was considered as a rustic crop, under the soil and climatic conditions in the Paraiba semi-arid region, its production responds to the applications of N. Probably, due to the majority, the soils of the semi-arid regions present deficits in the supply of organic matter and macronutrients (Medeiros et al., 2015, 2017).

Our results for the NFP were similar to the 37 fruits obtained by Oliveira et al. (2014) in the okra culture of Santa Cruz. Firoz (2009) observed a linear increase in the NFP of okra, finding a higher value (20 fruits) with the maximum Rate of $\mathrm{N}\left(120 \mathrm{~kg} \mathrm{ha}^{-1}\right)$. Cardoso and Bernin (2012) evaluated the application of $\mathrm{N}$ on oat growth and yield and found 36 NFP at $115 \mathrm{~kg} \mathrm{ha}^{-1}$. Regarding PROD, the values verified by Oliveira et al. (2003) with the okra cultivar Santa Cruz was lower to that of the present work. These authors found $833 \mathrm{~g}$ with a Rate of $141 \mathrm{~kg}$ $\mathrm{ha}^{-1}$ of N. The results observed by Cardoso and Bernin (2012) with okra cultivar Dardo were much higher than those found in this study. These authors verified 4,051 $\mathrm{g} \mathrm{plot}^{-1}$, applying the Rate of $121.5 \mathrm{~kg} \mathrm{ha}^{-1}$ of N. Probably, this great difference observed between the productions is related to the genetic characteristics of each cultivar, besides the soil and soil conditions of the crops regions, since the work of the authors was conducted in the Amazon region.

Significant additions of NFP and okra production with increasing N Rates occurred due to the absorption of this nutrient in larger quantities by the crop. This element, when supplied in adequate amounts, promotes significant increases in the stages of growth and development of plants, as they participate in their metabolism through enzymes, amino acids, proteins, pigments and nucleic acids, fundamental constituents of protoplasm, and chlorophyll during the process of photosynthesis (Oliveira et al., 2003; Akande et al., 2010; Olaniyi et al., 2010; Oliveira et al., 2014; Medeiros et al., 2015; Souza et al., 2017).

\section{Conclusions}

Nitrogen fertilization provided increases in the leaf area and the number of fruits and okra production.

The nitrogen Rate of $200 \mathrm{~kg} \mathrm{ha}^{-1}$ promoted the highest yield of okra fruits.

The wastewater use constituted a potentially viable water source for the cultivation of okra cv. Santa Cruz on the Paraíba semi-arid region. 


\section{References}

Akanbi, W. B., Togun, A. O., Adediran, J. A., \& Ilupeju, E. A. O. (2010). Growth, dry matter, and fruit yields components of okra under organic and inorganic sources of nutrients. American-Eurasian Journal of Sustainable Agriculture, 4(1), 1-13.

Akande, M. O., Oluwatoyinbo, F. I., Makinde, E. A., Adepoju, A. S., \& Adepoju, I. S. (2010). Response of okra to organic and inorganic fertilization. Nature and Science, 8(11), 261-266.

Akintomide, T. A., \& Osundare, B. (2015). Growth and yield responses of okra (Abelmoschus esculentus) and soil fertility status to NPK fertilizer application regimes. International Journal of Research Studies in Agricultural Sciences, 1(3), 11-16.

Anjos, F. A., Azevedo, C. A. V., Ferraz, R. L. S., Souza, J. L., Lima, V. L. A., \& CavalcanteJúnior, C. A. (2017). Production components and water use efficiency of corn under irrigation depths. Australian Journal of Crop Science, 11(12), 1609-1616. https://doi.org/10.21475/ajcs.17.11.12.pne795

Cardoso, M. O., \& Berni, R. F. (2012). Nitrogen applied in okra under non-tightness grown and residual fertilization. Horticultura Brasileira, 30(4), 645-652. https://doi.org/10.1590/S0102-05362012000400014

CONAMA (Conselho Nacionaldo Meio Ambiente). (2005). Resolução no 357 de 17 de março de 2005 (p. 23 ). Diário Oficial da República Federativa do Brasil, Brasília, Brasil.

Embrapa (Empresa Brasileirade Pesquisa Agropecuária). (1997). Manual de métodos de análise de solo (p. 212). Centro Nacional de Pesquisa de Solos, Rio de Janeiro, Brasil.

Ferraz, R. L. S., Barbosa, M. A., Viegas, P. R. A., Costa, P. S., Melo, A. S., Magalhães, I. D., ... Medeiros, A. S. (2017). Nutritional status of orange tree 'Pêra Rio' variety after Huanglongbing disease infection, leaf spray fertilization and application of resistance-inducing bioinductors. Australian Journal of Crop Science, 11(12), 1642-1650. https://doi.org/10.21475/ajcs.17.11.12.pne865

Ferreira, D. F. (2014). SISVAR: A guide for its bootstrap procedures in multiple comparisons. Ciência e Agrotecnologia, 38(2), 109-112. https://doi.org/10.1590/S1413-70542014000200001

Firoz, Z. A. (2009). Impact of nitrogen and phosphorus on the growth and yield of okra [Abelmoschus esculentus (L.) Moench] in hill slope condition. Bangladesh Journal of Agriculture Research, 34(4), 713-722. https://doi.org/10.3329/bjar.v34i4.5846

Kummer, A. C. B., Grassi Filho, H., Lobo, T. F., \& Lima, R. A. S. (2017). Fertilizante orgânico composto e água residuária no desenvolvimento de trigo irrigado por gotejamento. Irriga, 22(2), 275-287. https://doi.org/ 10.15809/irriga.2017v22n2p275-287

Medeiros, A. S., Nobre, R. G., Campos, A. C., Queiroz, M. M. F., Magalhães, I. D., \& Ferraz, R. L. S. (2017). Características biométricas e acúmulo de fitomassa da berinjeleira sob irrigação com água residuária e doses de nitrogênio e fósforo. Revista Brasileira de Agricultura Irrigada, 11(7), 1975-1985. https://doi.org/ 10.7127/rbai.v11n700665

Medeiros, A. S., Nobre, R. G., Ferreira, E. S., Araújo, W. L., \& Queiroz, M. M. F. (2015). Crescimento inicial da berinjeleira sob adubação nitrogenada e fosfatada e irrigada com água de reuso. Revista Verde de Agroecologia e Desenvolvimento Sustentável, 10(3), 34-40. https://doi.org/10.18378/rvads.v10i3.3656

Olaniyi, J. O.,Akanbi, W. B., Olaniran, O. A., \& Ilupeju, O. T. (2010). The effect of organo-mineral and inorganic fertilizers on the growth, fruit yield, quality and chemical compositions of okra. Journal of Animal \& Plant Sciences, 9(1), 1135-1140.

Oliveira, A. P., Alves, A. U., Dornelas, C. S. M., Silva, J. A., Pôrto, M. L., \& Alves, A. U. (2003). Rendimento de quiabo em função de doses de nitrogênio. Acta Scientiarum Agronomy, 25(2), 265-268. https://doi.org/ 10.4025/actasciagron.v25i2.1761

Oliveira, A. P., Oliveira, A. N., Silva, O. P. R., Pinheiro, S. M., \& Gomes Neto, A. D. (2013). Rendimento do quiabo adubado com esterco bovino e biofertilizante. Semina: Ciências Agrárias, 34(6), 2629-2636. https://doi.org/10.5433/1679-0359.2013v34n6p2629

Oliveira, A. P., Silva, O. P. R., Silva, J. A., Silva, D. F., Ferreira, D. T. A., \& Pinheiro, S. M. G. (2014). Produtividade do quiabeiro adubado com esterco bovino e NPK. Revista Brasileira de Engenharia Agrícola e Ambiental, 18(10), 989-993. https://doi.org/10.1590/1807-1929/agriambi.v18n10p989-993 
Omotoso, S. O., \& Shittu, O. S. (2007). Effect of NPK Fertilizer rates and method of application on growth and yield of okra (Abelmoschus esculentus L. Moench) at Ado-Ekiti Southwestern, Nigeria. International Journal of Agricultural Research, 2(7), 614-619. https://doi.org/10.3923/ijar.2007.614.619

Severino, L. S., Cardoso, G. D., Vale, L. S., \& Santos, J. W. (2005). Método para determinação da área foliar da mamoneira (Embrapa Algodão, Boletim de Pesquisa e Desenvolvimento, 55, p. 20). Embrapa Algodão, Campina Grande, Brasil.

Sousa, E. P. (2015). Qualidade físico-química e microbiológica de água residuária doméstica pós-tratada em fluxo descendente intermitente (p. 90, Dissertação de Mestrado, Universidade Federal de Campina Grande, Pombal, Brasil).

Souza, Á. H. C., Rezende, R., Lorenzoni, M. Z., Seron, C. C., Hachmann, T. L., \& Lozano, C. S. (2017). Response of eggplant crop fertigated with doses of nitrogen and potassium. Revista Brasileira de Engenharia Agrícola e Ambiental, 21(1), 21-26. https://doi.org/10.1590/1807-1929/agriambi.v21n1p21-26

Souza, L. P., Nobre, R. G., Silva, E. M., Lima, G. S., Pinheiro, F. W. A., \& Almeida, L. L. S. (2016). Formation of 'Crioula' guava rootstock under saline water irrigation and nitrogen doses. Revista Brasileira de Engenharia Agrícola e Ambiental, 20(8), 739-745. https://oi.org/10.1590/1807-1929/agriambi.v20n8p 739-745

Zubairu, Y., Oladiram, J. A., Osunde, O. A., \& Ismaila, U. (2017). Effect of nitrogen fertilizer and fruit positions on fruit and seed yields of Okro (Abelmoschus esculentus L. Moench). Journal of Plant Studies, 6(1), 39-45. https://doi.org/10.5539/jps.v6n1p39

\section{Copyrights}

Copyright for this article is retained by the author(s), with first publication rights granted to the journal.

This is an open-access article distributed under the terms and conditions of the Creative Commons Attribution license (http://creativecommons.org/licenses/by/4.0/). 